\title{
Influence of FG Vega Technique on students' academic performance in science 8
}

Influência da Técnica FG Vega no desempenho acadêmico dos alunos em ciências 8

Influencia de la técnica FG Vega en el rendimiento académico de los estudiantes en ciencias 8

Franco Gil A. Vega

francogil.vega@deped.gov.ph Tarragona National High School, Davao Oriental, Philippines https://orcid.org/0000-0002-6124-9411

\author{
Merlyn M. Lasaca \\ merlynmlasaca.63@gmail.com \\ Davao Oriental Division, Davao Oriental, Philippines \\ https://orcid.org/0000-0003-1241-0587
}

\begin{abstract}
This study was conducted to determine the influence of the FG Vega technique on students' academic performance to address the least learned competency in Science 8. Seventy students from Grade 8 classes served as respondents of the study. The study employed a quasi-experimental method. The mean score of students who took the post-test is 32.03 and 27.57 respectively for the experimental and control group. The results can be gleaned that the score of each student in the experimental group has a little variation of mean with 6.71 as compared to the control group with a variation of 7.52. The results can be observed that the mean score of students in the pre-test under the control group is 8.80 and 11.34 under the experimental group. Thus, the results of the study can be further concluded that the students under the experimental group outperformed the students in the control group. Since the significant level is lesser than the p-value of 0.05 , indicates that there is a significant difference between the pre-test and post-test under the experimental group. Hence, there is a significant difference between the post-test of the experimental and control group.
\end{abstract}

Keywords: FG Vega technique, academic performance, traditional teaching

\section{RESUMO}

Este estudo foi conduzido para determinar a influência da técnica FG Vega no desempenho acadêmico dos alunos para abordar a competência menos aprendida em Ciências 8. Setenta alunos da $8^{a}$ série serviram como respondentes do estudo. O estudo empregou um método quase experimental. A pontuação média dos alunos que realizaram o pós-teste é de 32,03 e 27,57, respectivamente, para o grupo experimental e controle. Os resultados podem ser apreendidos que a pontuação de cada aluno do grupo experimental tem uma pequena variação de média com 6,71 em comparação ao grupo controle com uma variação de 7,52. Os resultados podem ser observados que a pontuação média dos alunos no pré-teste no grupo controle é de 8,80 e 11,34 no grupo experimental. Assim, os resultados do estudo podem ser concluídos ainda que os alunos do grupo experimental superaram os alunos do grupo de controle. Como o nível de significância é menor que o valor p de 0,05 , indica que há uma diferença significativa entre o pré-teste e o pós-teste no grupo experimental. Portanto, existe uma diferença significativa entre o pós-teste do grupo experimental e controle.

Palavras-chave: técnica FG Vega, desempenho acadêmico, ensino tradicional

\section{INTRODUCTION}

Science allows students to explore their surroundings and come up with new ideas. Science is also an engaging topic with events that make it suitable for active learners (Barredo, 2013). Our students' poor performance prohibits them from becoming active participants in the development of a meaningful life. The Trends in Mathematics and Science Survey, conducted in 2015, obtained unsatisfactory results, with the Philippines ranking 42nd in Science out of 45 countries examined (Gurney, 2016). As a result, the Philippines ranked last in science literacy among 79 countries in the 2018 Program for International Student Assessment (PISA).

Students should be exposed to a variety of strategies for dealing with poor academic results. The researcher proposed the Franco Gil Vega (FGV) technique, which is thought to improve Sapienza: International Journal of Interdisciplinary Studies | Vol. 2 | n. 2 | Abr-Jun | 2021 | e-ISSN: 2675-9780 
student engagement in classroom activities and academic success. The FG Vega technique is based on the cooperative learning principle, which is used to develop learners' participation skills, according to the proponent. This approach is an example of an active teaching technique that can be used in the classroom.

The FG Vega Technique is used to promote student's social skills to avoid active students from dominating the classroom while inactive students are kept quiet. It means that using the FG Vega technique, every student has the opportunity to talk. Additionally, the FG Vega technique can improve students' ability to speak in front of others or the public, allowing them to present their ideas to a large audience. It is expected that using the FG Vega technique would help students in science 8 increase their academic performance. Later on, when students have a better understanding of the content, this interest has an impact on them, giving them the confidence to express their thoughts. As a result, it would foster a positive class environment and the creation of a democratic class. Students' interest in the topic could increase if this FG Vega technique is used as a learning method. As a result of the use of this innovative learning method, students are expected to increase their academic performance.

Given the importance of academic performance, secondary students should be given a plan that inspires them to work harder to increase their grades. If a student's science literacy skill is weak, secondary school is considered a difficult time to train and direct them to become what teachers expect. Improvements in secondary school students' performance, especially in Science 8, are expected to allow students to better understand scientific concepts and processes, allowing them to communicate and produce ideas more effectively, as well as engage more easily with their environments. It would be easier for someone who has acquired scientific literacy to express their ideas or concepts to others, and the effectiveness will be visible as listeners grasp the teacher's idea or concept (Kirshenbaum, 2009).

According to the results of an interview with an 8th-grade teacher at Tarragona National High School, most students find it difficult to understand the connections and processes, especially grade 8 science topics. The subject of study was linked to several students who were hesitant to learn. This point was reinforced by the Class Proficiency Level (CPL) for the first quarter, which was nearly identical to previous years. Furthermore, the findings of the observation revealed that the teaching paradigm is to blame for students' lack of scientific literacy. This shows that the teacher has not yet introduced a teaching model that will encourage students to take action and be courageous to grasp the subject, and the teacher has not yet increased student participation in learning activities.

The above-mentioned learning constraints can be overcome through innovative teaching methods. If the teacher presents a learning method that is critical for improving students' academic performance, the students would be more motivated to share their ideas. The FG Vega Technique is one of the learning methods that can be used to help students improve their science literacy. According to Zakrajsek (2017), student participation in the classroom is balanced; there are no students who dominate to express their opinions, no shy students, and no students who simply remain silent during a learning activity when the cooperative learning method is applied. Thus, the introduction of the FG Vega technique will assist teachers in identifying students who do not fully comprehend the subject.

For these purposes, the researcher will introduce the FG Vega technique in Science for Grade 8 students, which will aid in addressing the learners' least mastered competencies and thus help them improve their academic results. The FG Vega technique was first used in the Davao Oriental Division. 


\section{Statement of the Problem}

This study determined the influence of the FG Vega technique on the academic performance among grade 8 students of Junior High School in Tarragona National High School.

Specifically, the study sought to answer the following questions:

1. What is the level of academic performance of students based on the pre-test and post-test results using the two strategies?

1.1 traditional method; and

1.2 FG Vega technique?

2. Is there a significant difference that exists between the pre-test and post-test results between the traditional method; and the FG Vega technique?

\section{THEORETICAL FOUNDATION}

This research was anchored on Keller's (1983) theory of motivation and Olsen and Kagan's theory of cooperative learning (1992). Motivation, according to Keller (1983), is "the magnitude and direction of behavior." In other words, it applies to people's decisions on the experiences or goals they will pursue or avoid, as well as the amount of effort they will put forward in doing so." As a result, both internal and external factors will affect motivation right away. Motivation may therefore be both intrinsic and extrinsic.

Cooperative learning, according to Olsen and Kagan (1992), is a teaching method based on the transmission of information among group members who share the responsibility for individual and group performance. This implies that the heterogeneity of the groups is needed to achieve a common objective. Learners are assigned to groups of varying capacities in this situation, ensuring the attainment of social and academic goals while seeking results that benefit all group members.

Cooperative learning is a group learning activity organized such that learning is dependent on the socially structured exchange of information between learners in groups and in which each learner is held accountable for his or her learning and is motivated to increase the amount of time spent learning. Intrinsic motivation is described as motivation that occurs when an individual performing task experiences internally rewarding outcomes during or after.

\section{METHODOLOGICAL PROCEDURES}

This chapter presents the design, sampling, instrument, procedures, and data analysis.

\subsection{Research Design}

This research study used a quasi-experimental quantitative research design. According to Creswell, a quasi-experimental design is an experiment in which the researcher assigns participants to groups, but not at random, so the experimenter cannot construct groups artificially. 2 The researcher will also use the Pre- and Posttest design. According to Creswell (2012), a pre-test is a measurement of certain attributes or characteristics that will be measured for experiment participants before they undergo treatment. Meanwhile, a posttest is a measure of some attributes or characteristics that will be assessed for participants in an experiment after a treatment. 
This research used two groups for comparison. The first is the experimental group that was treated by FG Vega Technique. The second one is the control group that was treated by conventional strategy or not treated by the FG Vega technique.

\subsection{Respondents and Sampling}

The study was conducted during SY 2019 - 2020 at Tarragona National High School Junior High School, a government high school located at Poblacion Tarragona, Davao Oriental, Philippines. The school has a total of 1,030 Junior High students.

Grade 8 students were chosen as research participants. The Nonequivalent Control Group Design was used by the researcher. According to Gay (2012), the non-equivalent control group design entails the random assignment of intact groups to treatments rather than individuals. A total of 70 students participated in the study as respondents.

\subsection{Research Instrument}

The research instruments used in gathering the data have two parts, the pre-test/post-test, and the implementation of the FG Vega technique.

\section{Part I.- Pre-test/Post-test}

It is a 50-item teacher-made test in the form of 5 formative tests which was designed to measure the mastery level of the students on the lesson chosen by the researcher. The items in the test were subjected to the validity test.

The experimental group was exposed to the FG Vega technique while the control group used the traditional method of teaching. Likewise, a pre-test was given to both groups before the introduction of the lesson and a post-test after the end of the lesson. Both pre-test and post-test given to the experimental and control groups were the same.

The researcher constructed a 50-item multiple-choice test of 2 sets of questions for pre-test and post-test based on the Table of Specifications or Budget of Work while ensuring that the same competencies were measured. This was intended to measure the achievement or performance of both control and experimental groups. The standardized pre-test and post-test were given to the respondents for the fourth grading period. It must be made clear that the test given to the experimental class was also given in the control class. Further, the questions given in the pre-test are parallel questions given in the post-test.

The pre-test and post-test results of each group for the particular grading period are treated separately. However, to determine whether the achievement of the experimental class is better than the control class, the post-test results of both groups were computed using the T-test.

\section{Part-II. Experimentation Phase. of FG Vega technique}

This would be the conduct of experimentation that involved initially-class orientation. A pre-test for academic performance in Science 8 was given in both the experimental and control group and check if they are compared using a t-test.

The teacher began the lesson by explaining the FG Vega technique, stressing its characteristics as a business venture in which each student was given thirty (30) points as their capital entry. The students were expected to spend the points they were given by responding to the 
teacher's questions. Learners should devote time to studying the lesson while becoming familiar with the concepts of each topic to increase their capital points. However, if a student is unsure about his or her answer, he or she can save the remaining points to avoid losing capital if the incorrect answer comes.

In addition, if a student wishes to earn more points, he or she must correctly answer the questions. Since the FG Vega technique is based on cooperative learning theory, the points earned by students in the technique will be added to their performance task, as mentioned in DepEd Order 8, s. 2015, which emphasizes the Policy Guidelines on Classroom Assessment for the K to 12 Basic Education Program. Learners should be involved in the learning process individually or collaborate with teammates over some time as part of the performance task. As a result, the DepEd order emphasized students' freedom to express their learning in appropriate and diverse ways.

Depending on the task, learners have 30 seconds to talk or participate. Students were encouraged to take an active role in their education. As a result, each learner will receive a maximum of 10 points for the entire class session. Students who do not participate in the discussion should speak up by commenting on the evidence presented or their opinion of a peer.

\subsection{Data Gathering Procedures}

A formal permission letter was secured from the Schools Division Superintendent to conduct the study through the recommendation of the Education Program Supervisor in Science of Davao oriental Division. A letter of recommendation was obtained from the office of the Schools Division Superintendent and was presented to the school principal of Tarragona National High School for the researcher to be allowed to conduct the study.

The respondents were given a briefing and explanation of the study's purpose, as well as guarantees that any information they provided would be kept fully confidential. To obtain accurate and relevant results, the researcher specified and clarified all instructions. As a result, a letter of parental consent was sent to selected respondents, requesting that their son or daughter participate in the study. Since they were under the age of 18 , parental consent was required before they could participate in the study. Just 70 respondents were able to participate in the study after the parent consent was obtained and collected from the selected respondents.

\subsection{Data Analysis}

For analysis and interpretation of the data, the following statistical tools were used.

For objective number one, the mean of response and standard deviation generated to provide the general level of influence of using the FG Vega technique on students' academic performance.

For objective two, the T-test was the statistical tool used to determine the significant impact of the FG Vega technique on the performance of Grade 8 science students.

T-value and P-Value were used to define the significant difference that exists between the pre-test and post-test results using the two strategies in teaching Science: traditional method and the use of FG Vega technique.

\section{RESULTS AND DISCUSSION}


This chapter examines the presentation and analysis of data based on the academic performance of Junior High School students using the FG Vega technique from a random sample of Tarragona National High School, Junior High School students. The data were presented in a tabular form with numerical descriptions, which answered the problem at hand. The data is presented in such a way that it provides the study's readers with straightforward and reliable details.

The data on the influence of the FG Vega technique on students' academic performance is presented in the tables, statistics, and explanations below. Furthermore, the following data was used to see whether there was a significant difference between the pre-test and post-test results for the traditional method and the FG Vega technique.

\subsection{Level of students' Science performance based on the pre-test and post-test}

The set of observations from the results of the examination administered during the pre-test and post-test of the control and experiment groups are summarized in Table 1. It is shown that the student's score in the examination has been distributed based on the minimum and maximum scores obtained.

Table 1: The Level of Students' Performance under the Experimental and Control Group

\begin{tabular}{|l|c|c|c|}
\hline \multicolumn{1}{|c|}{ Observed Assessment } & Cases & $\begin{array}{c}\text { Standard } \\
\text { Deviation }\end{array}$ & Mean \\
\hline Pre-test Experimental & 35 & 2.42 & 11.34 \\
\hline Post-test Experimental & 35 & 6.71 & 32.03 \\
\hline Pre-test Control & 35 & 3.01 & 8.80 \\
\hline Post-test Control & 35 & 7.52 & 27.57 \\
\hline
\end{tabular}

Now looking at the post-test results from both the control and experimental groups. The experimental and control groups have mean scores of 32.03 and 27.57, respectively, on the posttest. The results show that each student in the experimental group has a small mean variation of 6.71, compared to the control group, which has a mean variation of 7.52.

According to Boaler (2002), conventional science students perceived science as a series of procedures. Students who were taught in a sense, on the other hand, saw Science as an involved, inquiry-based discipline. The FG Vega technique is evaluated in comparison to the traditional method of teaching and learning Science.

The findings show that the control group's mean pre-test score is 8.80 , while the experimental group's mean pre-test score is 11.34 . It has a slight difference of 3.34 , and the control group's student score varies from the mean at the ranges of 3.01, whereas the experimental group's score varies from the mean at ranges of 2.42. There is a small difference between the measures of a central location, but it is negligible.

In general, there is no difference in students' science performance based on the pre-test. The study's findings also revealed that students in the experimental group outperformed those in the control group.

The findings of the study back up the findings of Majoka, Dad, and Mahmood (2010), who found that cooperative learning is a more effective teaching paradigm for Science than the traditional method of teaching. It proved to be an active learning technique because it allowed for greater learning interaction. 
Rattanatumma \& Puncreobutr (2016) also discovered that cooperative learning is more effective than traditional teaching in improving science students. Molla, \& Muche (2018), on the other hand, found that students who were exposed to traditional teaching performed substantially better than students who learned through cooperative learning.

\subsection{The Difference between Pre-test and Post-test of Control and Experimental Group}

The t-test statistic is used to assess the differences. The results of the computation are summarized in Table 3.

Table 3: The Difference between Pre-test and Post-test of Control and Experimental Group

\begin{tabular}{|c|c|c|c|c|c|c|}
\hline \multirow[b]{2}{*}{ Observed Assessment } & \multirow[b]{2}{*}{ Mean } & \multicolumn{2}{|c|}{ Paired Differences } & \multirow[b]{2}{*}{$\mathrm{T}$} & \multirow[b]{2}{*}{ df } & \multirow[b]{2}{*}{$\begin{array}{l}\text { Sig. } \\
\text { tailed) }\end{array}$} \\
\hline & & Mean & $\begin{array}{l}\text { Std. } \\
\text { Deviation }\end{array}$ & & & \\
\hline Post-test Experimental & 32.02 & \multirow{2}{*}{20.68} & \multirow{2}{*}{5.72} & \multirow{2}{*}{21.36} & \multirow{2}{*}{34} & \multirow{2}{*}{.000} \\
\hline Pre-test Experimental & 11.34 & & & & & \\
\hline Post-test Control & 27.57 & \multirow{2}{*}{18.77} & \multirow{2}{*}{5.21} & \multirow{2}{*}{21.301} & \multirow{2}{*}{34} & \multirow{2}{*}{.000} \\
\hline Pre-test Control & 8.80 & & & & & \\
\hline Post-test Experimental & 32.02 & \multirow{2}{*}{4.45} & \multirow{2}{*}{7.70} & \multirow{2}{*}{3.42} & \multirow{2}{*}{34} & \multirow{2}{*}{.002} \\
\hline Post-test Control & 27.57 & & & & & \\
\hline
\end{tabular}

The difference in mean score between the experimental group's post-test and pre-test is 20.68, and it differs just 5.72 units from the mean, according to the study's results. The significant level is.000, and the t-test value is 21.36 with 34 degrees of freedom. Since the significant level is less than 0.05, it means there is a significant difference between the pre-test and post-test in the experimental group.

The mean difference between post-test and pre-test for the control group is 18.77, with a small variation in individual student scores of approximately 5.21. With a significant level of 0.000 , the t-test value is 21.301 and the degree of freedom is 34 . The significant level obtained by computation is smaller than the $0.05 \mathrm{p}$-value. This means that there is a significant difference between the control group's post-test and pre-test.

The last comparison is the post-test between the experimental and control group. The mean score varies by 4.45 units, and the individual score differs by 7.70 units from the mean. The t-test values are $t=3.42$ with 34 degrees of freedom and a significant level of 0.002 , which is less than the p-value of 0.05 . As a result, there is a significant difference between the experimental and control groups' post-test results. Rattanatumma \& Puncreobutr (2016) affirm the findings of the report, finding a significant difference between cooperative learning and traditional teaching in terms of science learning achievement.

\section{CONCLUSION}

Based on the findings of the study, the following conclusions were drawn:

The findings and discussions discussed in the results and discussions section served as strong evidence to back up the study's findings. This can also be used to conclude these important findings. As a result, the conclusions that follow are based on the study's two (2) goals.

The results showed that the mean pre-test score of students in the control group varies significantly from the experimental mean and that the control group's score differs from the experimental mean. The experimental group outperformed the control group, according to the study's findings. 
The study's results indicate that the experimental group's mean score difference between post-test and pre-test is significantly different from the mean. Since the significant level is less than the p-value, there is a significant difference between the pre-and post-tests in the experimental group. The mean difference between post-test and pre-test for the control group has a small variation in individual student scores. The significant level predicted value is less than the $p$-value. This means that there is a significant difference between the control group's post-test and pre-test.

The post-test between the experimental group and control group is the last comparison. Away from the mean, the difference between the mean and the individual score varies accordingly. As a result, there is a significant difference between the experimental and control groups' post-test results.

\section{REFERENCES}

Barredo, K.J. (2013). "Development on the Academic Performance in Science using Strategic Intervention Material." Retrieved from https://www.scribd.com/document/296475030/Development-on-the-Academic-Performancein-Science

Boaler, J. (2002). Experiencing school mathematics: Traditional and reform approaches to teaching and their impact on student learning. Mahwah, NJ: Lawrence Erlbaum

Creswell, J. W. (2012). Educational research: Planning, conducting, and evaluating quantitative and qualitative research (4th ed.). Upper Saddle River, NJ: Pearson Education.

RepEd Order s. 2015 Bolicy Guidelines on Glassom, Assessment for the Ko to 12.Basic Education Program.

Gay, L. R., Mills, G. E., \& Airasian, P. W. (2012). Educational research: competencies for analysis and applications. 10th ed. Boston: Pearson.

Gurney, J. (2016). "Revealed: World pupil rankings in science and maths - TIMSS results in full." Telegraph Education. Retrieved from https://www.telegraph.co.uk/education/2016/11/29/revealed-world-pupil-rankingsscience-maths-timss-results

Keller, J. M. (1983). Motivational design of instruction. In C. M. Reigeluth (Ed.), Instructional design theories and models: An overview of their current status (pp. 383- 434). Hillsdale, NJ: Erlbaum

Kirshenbaum, S. (2009). What Is Scientific Literacy?. Retrieved from https://www.discovermagazine.com/thesciences/what-is-scientific-literacy-02

Majoka, M. I., Dad, M. H., \& Mahmood, T. (2010, December). Student team achievement division (STAD) as an active learning strategy: Empirical evidence from mathematics classroom. Journal of Education and Sociology, p. 16

Molla, E., \& Muche, M. (2018). Impact of Cooperative Learning Approaches on Students' Academic Achievement and Laboratory Proficiency in Biology Subject in Selected Rural Schools, Ethiopia. Education Research International Volume 2018, Article ID 6202484, 9 pages https://doi.org/10.1155/2018/6202484

Olsen, R. E., \& Kagan, S. 1992. About cooperative learning. In C. Kessler (Ed.). Cooperative language learning: A teacher's resource book pp. 1-30. Englewood Cliffs, NJ: Prentice-Hall.

Rattanatumm, T., \& Puncreobutr, V. (2016). Assessing the effectiveness of the STAD model and problem-based learning in mathematics learning achievement and problem-solving ability. Journal of Education and Practice, 7(12), 194-199.

Serdyukov, P. (2017). Innovation in education: what works, what doesn't, and what to do about it?", Journal of Research in Innovative Teaching \& Learning, Vol. 10 No. 1, pp. 4-33. https://doi.org/10.1108/JRIT-10-20160007

Zakrajsek, T. (2017). Students Who Don't Participate in Class Discussions: They Are Not All Introverts. Associate Professor - University of North Carolina at Chapel Hill. Retrieved from https://www.scholarlyteacher.com/post/students-who-dont-participate-in-class-discussions 